\title{
Identification of Worm Eggs in Faeces of Egrets (Egretta sp.) in Surabaya
}

\author{
Identifikasi Telur Cacing pada Feses Egrets (Egretta sp.) di Surabaya
}

\author{
${ }^{1)}$ Akbar Haryo Widhi Trismiharto, ${ }^{2)}$ Suzanita Utama, ${ }^{3)}$ Koesnoto Soepranianondo, ${ }^{4}$ Djoko \\ Poetranto, 5) Setiawan Koesdarto, 5) Muchammad Yunus \\ ${ }^{1)}$ Student, ${ }^{2}$ Department of Veterinary Reproduction, ${ }^{3}$ Department of Animal Husbandry ${ }^{4}$ Department of \\ Veterinary Clincal, ${ }^{5}$ Department of Veterinary Parasitology. Faculty of Veterinary Medicine, Universitas \\ Airlangga.
}

\begin{abstract}
The aim of this research was to identify worm eggs species that infected Egrets in Surabaya. A total of 40 samples were taken and faecal examination was conducted in the Laboratory by means of native, sedimentation, and floating methods, In floating method saturated brown sugar solution was used as floating media because brown sugar solution was faster in floating worm eggs. Then further examination of the worm eggs species were matched by microscopic taxonomy and textbook comparison observation. Eggs of three classes of helmints, Trematode, Cestode, and Nematode were found in faeces of Egrets in Surabaya. Species of the Nematode eggs found were Ascaris sp., Ascaridia galli, , Capillaria sp., Toxocara cati. Species of Cestode class egg found were Raillietina sp, from Trematode class were Echinostoma revolutum.
\end{abstract}

Key words: Worms Eggs, Egretta sp., Brown sugar.

\section{Introduction}

Indonesia is a maritime country, with the geographical location exactly on the the equator line. This country has more than 17,500 large and small islands, has more than 42 types of terrestrial and five types marine ecosystems very unique. The diversity and uniqueness of the ecosystem has made awarded in term of natural resources. There is no other country which has natural conditions such as Indonesia. Indonesia is the richest country in the world in terms of biodiversity. World Resource Institute, IUCN, dan UNED (1995) described that Indonesia has up to $25 \%$ various species in the world when its land area is only $1.3 \%$ of the total mainland in the world (Sukara 2008).

This is due to the geographical location of Indonesia that is strategic because it is located between two continents, Asia and Australia and between two oceans, the Hindia ocean and the Pacific as well as a meeting between two important biogeographic region that is Oriental and Australian region. This conditions made Indonesia the world's most unique area (Sukara,
2008). These unique conditions made Indonesia rich in term of palnts and animals.

Indonesia has a lot of diversity in various kind of animal species or wildlife, one of them is the kinds of birds. The number of bird species in Indonesia account for $18 \%$ from the total of birds species in the world (1598). Indonesia also became a part of the flight paths of 149 species migratory birds (Sukmantoro et al., 2007). Migratory birds are birds that do the flying activity from breeding location to non breeding location that occur every year. Migration of these birds as a form of response due to the extreme climate change. Several types of habitat that support migratory birds are the mountains, swamps, coastal waters, lakes, mangroves and mudflats because its providing various sources of food (Howes et al., 2003).

The time when migratory birds start migrating to the southern hemisphere are from October to December. Location that will be visited by migratory birds to find food are the mangrove, beach, mudflats, rice field and swamp. 
The stopover place of these migratory birds can be a source of disease transmission which could infect the birds in Indonesia, because this can increase the density of the groups of birds. This incident that increased the risks of disease transmission to local birds that foraging at the same spot with migrant birds (Whitworth et al., 2008). One of the Indonesia bird that inhabit at mangrove, mudflat, rice field and the foraging activity at the same time with the migrant birds are the egrets (Howes et al., 2003)

Egrets are the water birds with medium body size that usually can be found in mangrove areas and rice field areas at tropical country such as Indonesia. These birds are included in the family Ardeidae and can be identified from the size of the neck that is long enough and slightly curving, long legs and dark colored for several species of egrets (Mackinnon, 200o). Egrets started their hunting activity during the day while walking through shallow mudflat, open water and stabing prey with its bill (Kazantzidis and Goutner, 1996). Egrets mainly eat small fish size 1.2 up to $6 \mathrm{~cm}$, but crustacean, bivalves and other invertebrate also consumed (Elfidasari, 2008).

Egrets in Indonesia are often looking for its prey in the mangrove and rice field. These two areas provide different food sources (Elfidasari, 2008). Mangrove areas provide food such as crustacean and small fish, while rice fields areas provide grasshooper, beetle, and other arthropods as the sources of food (Abdullah et al., 2016). Opportunistic hunter is the nickname for egrets when looking for its prey, they depend on visual cues that was shown by its prey, when there is small movement shown by its prey, egrets will immediately stabs with its bill ( Kazantzidis and Goutner, 1996 ).

East Java especially Surabaya is one of the biggest city in Indonesia that has suitable habitat for egrets as well as migratory birds when stop by, this location is Wonorejo. Wonorejo is one area on the east coast of Surabaya consisting of fishpond area and mangrove area which is influenced by the tides so that presents a vast wetland for feeding grounds for birds (Lukman, 2010). Wonorejo also one of Important Bird Area (IBA) which has been established by birdlife Indonesia as a temporary stopover areas to looking for food for birds that migrate, because almost every year will be visited by more than 10,000 pairs of birds, especially water birds. Water bird species that are often found in Wonorejo is Ardeidae family, egrets including on it. Egrets in Wonorejo utilize these areas such as muudy areas, fishpond and rivers as as feeding grounds (foraging) and mangrove vegetation for perch and nesting (Tri, and Trisnawati 2013), because of the location for foraging of migratory birds and egrets in Surabaya is the same, that is Wonorejo, so contact between these birds could not be avoided dan the risk of disease transmission between species is also high. egrets as one of the wildlife that commonly found in Surabaya need to be aware of its existence.

he emergence of a disease can be caused by the types of organisms such as virus, bacterial, fungus, tick, and lice, but most widely spread is worm (Kusumamiharja, 1986). Parasites, especially worms could decrease the condition of the host because it could disturb the absobtion of the nutrient, damage the tissue and sucking blood on host. This could lead to serious problems such as metabolism problem and organ damage so the body organs could not function properly (Kusnoto et al, 2014).

The reason why the researcher choose to identify the worm egg on the egrets as the subject of the research because to determine the types of worms that infect the egrets and to be able carry out further study on diseases in wildlife with the hope could support wildlife conservation in Indonesia.

\section{Materials and Methods Samples Handling}

The samples that used in this research were used fresh feces samples of wild egrets that temporary nest in Surabaya Zoo. Faeces were taken and put into plastic pot and filled with $10 \%$ formalin. Each pots was labeled or marked with samples number that adjusted for sample collection. Faecal samples brought to the Laboratory of Parasitology Faculty of Veterinary Medicine, Surabaya to be examined.

\section{Sample Examination}

Identification was carried out by observing worm eggs isolated from faecal sample, by means of native, sedimentation, and floating methods. 
The species of worm eggs found were identified against reference picture (Soulsby, 1986)

\section{Native Method}

Faeces was taken by using the tip of a glass stirrer and smeared on object glass. One to two drops of water was added and mixed well using glass stirrer and covered with cover glass. Then examined under a microscope with oox magnification (10x Objective) (Mumpuni et al., 2016).

\section{Sedimentation Method}

Stool was made into suspension with a ratio of 1 part feces and 10 parts water then filtered through a tea strainer and then put into conical tube. Suspension was centrifuged at 1500 rpm for 5 minutes. After that supernatant was discarded, sediment was topped up with water and centrifuged again for 5 minutes. This process was performed several times until the supernatant was clear. Supernatant was then discarded, leaving a little bit of it sediment. Sediment was stirred and a bit of sediment was taken by using a pasteur pipette. The Sediment of faeces was dropped on object glass and covered using cover glass. Then examined under a microscope with 10ox magnification (10x Objective) (Mumpuni et al., 2016).

\section{Floating Method}

After examination of faeces sample using sedimentation method, the sediment of faeces was topped up with saturated brown sugar solution up to $1 \mathrm{~cm}$ before the top of conical tube and then centrifuged at 1500 rpm for 5 minutes. For floating media brown sugar solution was used because the brown sugar solution has lower viscosity value so brown sugar solution has value of specific gravity at $\mathbf{1 . 2 0}$, therefore brown sugar solution is faster in floating the egg worms (Poetranto, 1992).

After centrifugation, conical tube was placed on tube rack and slowly topped up with brown sugar solution until the surface of the solution showed convex form. Cover glass was placed gently on the top of the tube and left for 12 minutes. Then, cover glass was taken and placed on object glass and examined under a microscope with 100x magnification (Objective 10x) (Mumpuni et al., 2016).

\section{Results}

In this study, 40 samples of feces was collected in one day, from 40 samples examined, 39 was positive contained helminth eggs. Type of worm eggs found included three classes of helmint that are Trematode, Cestode, and Nematode. Species of worm eggs found from the class Nematode were Ascaris sp., Ascaridia galli, Capillaria sp. Species of worm egg from class Cestoda that found in feces of egrets in Surabaya were Raillietina $s p$, then from Trematode class was Echinostoma Revolutum. Table 1 and Figure 1, 2, and Figure 3. showed the result of identifycation of worm eggs from faeces of egrets in Surabaya.

Table 1. Species of Worm Eggs That Found in Feces of Egrets in Surabaya

\begin{tabular}{llc}
\hline Class & Species & Percentage \\
\hline Trematode & Echinostoma & $85 \%$ \\
& Revolutum & \\
Cestode & Davainea proglottina & $2.5 \%$ \\
Nematode & Ascaris sp. & $97.5 \%$ \\
& Ascaridia galli & $2.5 \%$ \\
& Capillaria sp. & $2.5 \%$ \\
\hline
\end{tabular}
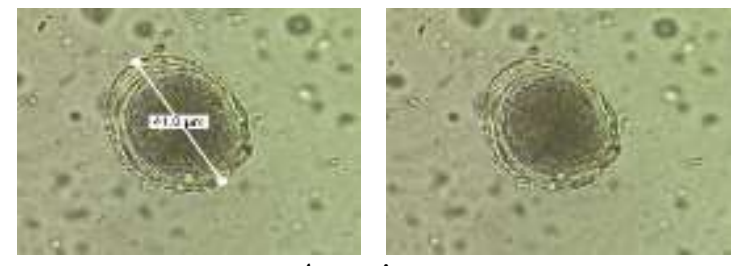

Ascaris sp.
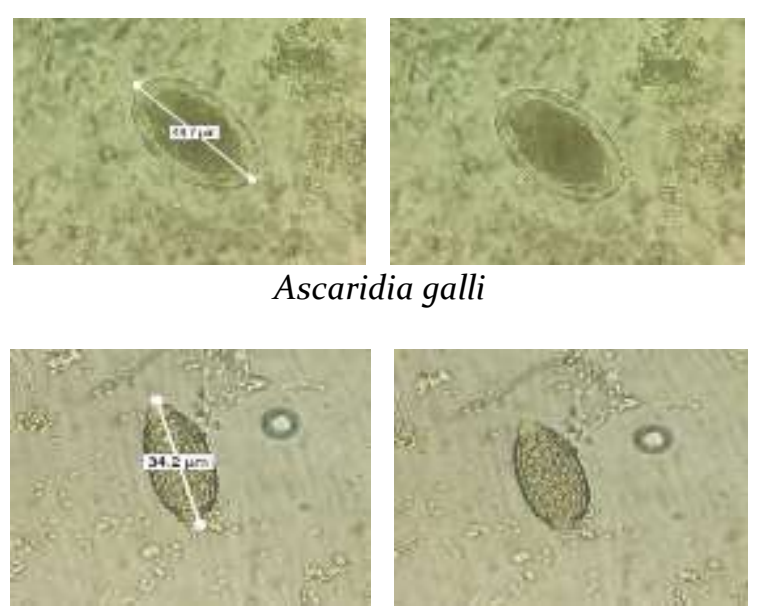

Capillaria sp.

Figure 1. Figure of Nematode Eggs That Found in Feces of Egrets in Surabaya. 


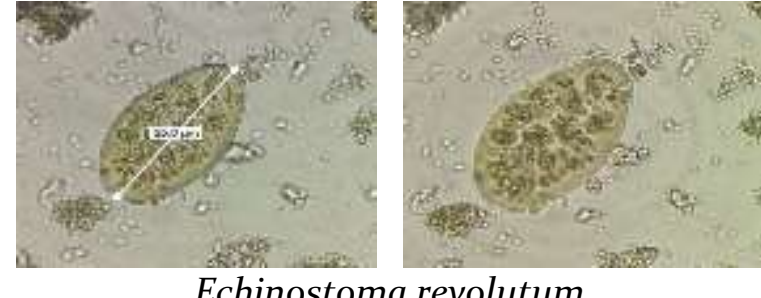

Echinostoma revolutum

Figure 2. Figure of Trematode Eggs That Found in Feces of Egrets in Surabaya.

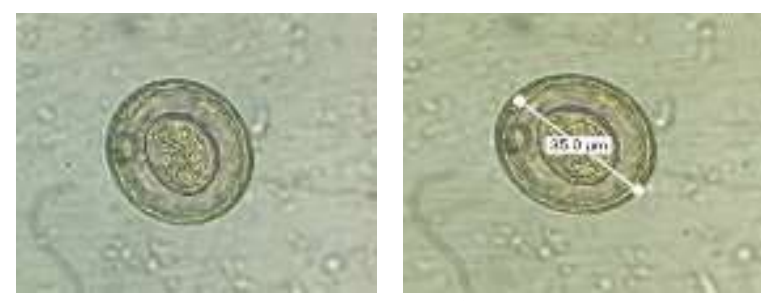

Davainea proglottina

Figure 3. Figure of Cestode Eggs That Found in Feces of Egrets in Surabaya.

\section{Discussion}

Based on the research that has been done, five species of eggs worms were found in feces of Egrets in. Out of the 40 samples was examined, 39 samples was positive contain the worm eggs.

Even though Egrets is easy to find in Surabaya and various places in Indonesia, however the attention to the existence of helminthiasis infection in these species of waterbirds should not be ignored because Egrets could be a mediator helminthiasis diseases that zoonotic for example Echinostomiasis. Atkinson (2008) stated that infection of Echinostoma revolutum can occur limited to duck and some species of waterfowls/waterbirds. Besides Egrets as mediator of diseases, climate in the environment also plays a role in the spread of the helminthiasis diseases. Wijaya (2015) stated that risk factors that cause the infection of worm eggs occur in areas with high humidity and high enough of rainfall in each year, so in Indonesia worm eggs and worm infection itself is quite high because climate of Indonesia is supportive in occurrence of infection.

The environmental conditions where there is a pile of feces, the pile of feces is a development field of worm larvae to become infective larvae (Soulsby, 1986). Besides being affected by season and environment, the spread of parasitic diseases in infecting host can be through food, drink, or soil contaminated with worm eggs that containing infective larvae (Wijaya, 2015). One important factor in the occurrence of parasitic worm infections is the immune system of animals (Levine, 1990). Some factors that can suppress the immune system against parasites and support predisposition parasite infection in the host are the density of a group of animals, poor hygienic condition, contaminated soil and contact between wild birds( LaMann, 2010).

This research has found five species of worm eggs in feces of Egrets in Surabaya, that are Ascaris spp., Ascaridia galli, Capillaria sp., Davainea proglotina, and Echinostoma revolutum. The size of Ascaris spp. worm eggs that found is $41 \mu \mathrm{m}$. Levine (1990) stated that the size of the eggs of Ascaris suum is $50-80 \times 40-60 \mu \mathrm{m}$, while the sized eggs of Ascaris Columnaris 88-90 x 66$68 \mu \mathrm{m}$. The eggs of Ascaridia galli also found and hte size is $44.7 \mu \mathrm{m}$. Levine (1990) stated that the size of the eggs of Ascaridia galli around 75-80 x 45-50 $\mu \mathrm{m}$. Capillaria sp. worm egg also found and the size is $34.2 \mu \mathrm{m}$. Size of Capillaria $s p$. worm egg according to Levine (1990) is 46-70 x 24-28 $\mu \mathrm{m}$.. The worm eggs from Cestode class that found is Davainea proglotinna sp. with size $35 \mu \mathrm{m}$ in diameter. Levine (1990) stated that the diameter of the worm eggs of Davainea proglottina is $\pm 28-40 \mu \mathrm{m}$. The worm eggs from Trematode class that found is Echinostoma revolutum and the size is $55 \mu \mathrm{m}$. Levine (1990) stated that the size of the worm eggs of Echinostoma revolutum is $50-90 \mu \mathrm{m}$ with operculum.

The identification results was found five species of worm eggs, that are Ascaris spp., Ascaridia galli, Capillaria sp., Davainea proglottina, dan Echinostoma revolutum. Fowler (2003) stated that Ascaridia galli infection in waterbirds was a common problem in waterfowl and the other avian, as well as infections of Capillaria sp. was also common in poultry or in the other wild birds. In the othe side, infection of Davainea proglottina may occur in majority of birds in the world, and the infection occur if cysticercoids in intermediate host such as molusca was eatean by the birds (Levine, 1990). 
In this research also found eggs of Ascaris spp. were also found in a large amount, Levine (1990) stated that infection of Ascaris spp. may occur in the majority of wild animals especially carnivore. This statement is was in line with the report of Rudy (1987) found the Ascaris worm in large quantities in the digestive tract of Red-Tailed Hawk. In another case, Rismawati and coworkers (2013) also found the worm eggs of Ascaris sp. in small quantities in the intestine of Gallus domesticus in Pekanbaru. Transmission of Ascaris spp. eggs could be through food sources, water and other materials that were contaminated by feces containing infective eggs (Tabbu, 2003)

In this study the worm eggs of Echinostoma revolutum were also found. Infection of Echinostoma revolutum could occur limited to duck and some species of waterfowls/waterbirds (Atkinson, 2008). So it is possibly that Egrets is a mediator of Echinostoma revolutum that can cause Echinostomiasis which is a zoonotic diseases.

\section{Conclusion}

Based on the research has been done on the identification of worm eggs in the faeces of Egrets (Egretta sp.) in Surabaya it could be concluded that Species of worm eggs found in this study were Ascaris spp., Ascaridia galli, , Capillaria sp., Toxocara cati., Davainea proglottina, and Echinostoma Revolutum.

\section{References}

Atkinson, C. T., N. J. Thomas, and D. B. Hunter. 2008. Parasitic Diseases of Wild Birds. Wiley-Blackwell. USA. 226-289

Fowler, M. 2003. Zoo and Wild Animal Medicine. Elsevier Science. United States. 118-128.

Howes, J., D. Bakewel, Y. R. Noor. 2003. Panduan Studi Burung Pantai. Wetlands International- Indonesia Programme. Bogor. 4-24

Kazantzidis, S., V. Goutner. 1996. Foraging ecology and conservation of feeding habitats of little egrets (Egretta garzetta) in the Axios River Delta, Macedonia, Greece. Colonial Waterbirds, 19:115-121
Kusnoto, S. Subekti, S. Koesdarto, dan S. M. Sosiawati. 2014. Buku Ajar Helmintologi Kedokteran Hewan. Edisi 1. Zifatama Publisher. Sidoarjo

Kusumamiharja, S. 1986. Pengendalian dan Pemberantasaan Penyakit Cacing Poultry Indonesia. Edisi Juli No. 75. 25-26.

LaMann, G. V., 2010. Veterinary Parasitology. Nova Science Publisher, Inc. New York. 88

Levine, N. D. 1990. Parasitologi Veteriner. Gadjah Mada University Press. Yogyakarta. 113-293.

Lukman, N. 2010. Studi Kelimpahan dan Keanekaragaman Burung Air dan Sumber pakannya di Tambak Wonorejo, Surabaya [Skripsi]. Departemen Biologi. Fakultas Sains dan Teknologi Universitas Airlangga, Surabaya

Mackinnon, J., K. Phillips., and B. van Balen. 2000. Burung-Burung di Sumatera, Jawa, Bali dan Kalimantan. Puslitbang BiologiLIPI. Indonesia. 58-64.

Mumpuni, S. S., S. Subekti, S. Koesdarto, dan Kusnoto. 2016. Petunjuk Praktikum Ilmu Penyakit Helmin. Fakultas Kedokteran Hewan. Universitas Airlangga. Surabaya

Rismawati, Yusfiati, R. Mahatma, 2013. Endoparasit Pada Usus Ayam Kampung (Gallus domesticus) di Pasar Tradisional Pekanbaru. Fakultas Matematika dan Ilmu Pengetahuan Alam. Universitas Riau.

Rudy, C. 1987. A Case of Ascariasis in a Red-tailed Hawk.[11 April 2017]

Soulsby, E.J.L. 1986 . Helminths, Arthropds and Protozoa of Domesticated Animals- $7^{\text {th }}$ Edition. The English language book society and bailliere, Tindall. London. 767-773.

Sukara, E., I. SL. Tobing. 2008. Industri Berbasis Keanekaragaman Hayati, Masa Depan Indonesia. Vis Vitalis. 1: 1-12.

Sukmantoro, W., M. Irham, W. Novarino, F. Hasudungan, N. Kemp dan M. Muchtar. 2007. Daftar Burung Indonesia No. 2. Indonesian Ornithologist'Union, Bogor. 
Tabbu, C. R. 2003. Penyakit Ayam dan Penanggulangannya 2, Penyakit Asal Parasit Noninfeksius dan Etiologi Kompleks. Kanisius. Yogyakarta

Tri, A. A., I. Trisnawati D.T., dan Aunurohim. 2013. Kajian Bioekologi Famili Aedeidae di Wonorejo, Surabaya. Jurusan Biologi Fakultas Matematika dan Ilmu Pengetahuan Alam. Institut Teknologi Sepuluh Nopember. Surabaya.
Wijaya, N. H., 2015. Beberapa Faktor Risiko Kejadian Infeksi Cacing Tambang Pada Petani Pembibitan Albasia (Studi Kasus di Kecamatan Kemiri) [M.S. Thesis]. Program Magister Epidemiologi Pascasarjana. Universitas Diponegoro. Semarang. 